\title{
Valuing Florida Water Resources: Ecosystem Services That We Do not Notice but Still Value ${ }^{1}$
}

\author{
Tatiana Borisova, Fei He, Xiang Bi, and Kelly Grogan²
}

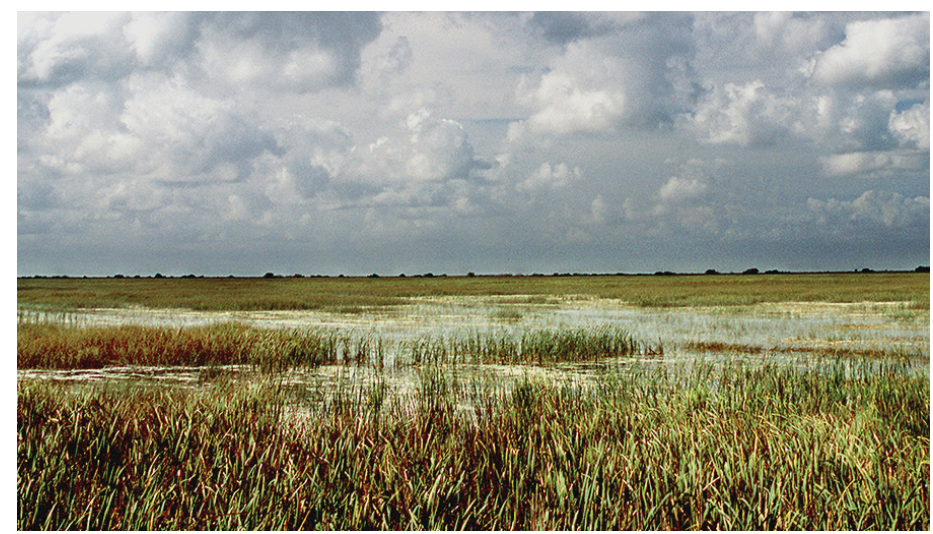

Figure 1. A hydrologic resoration project in Everglades National Park. Credits: UF/IFAS file photo

This article is a part of the EDIS series "Economic Value of Florida Water Resources" aimed at helping water-resource professionals and interested citizens learn more about measuring the economic value of Florida water resources. Tom Swihart, who worked in the Florida Department of Environmental Protection for three decades, called Florida's water "a fragile resource in a vulnerable state" (Swihart 2011). Indeed, despite the perception that water is bountiful in Florida, news stories about algal blooms, spring flow reductions, and droughts remind us that Florida's water resources require wise management. Yet management strategies can be costly. For example, the expenditures required for the Kissimmee River restoration were estimated at $\$ 980$ million (with the funding shared between federal and state sources, see SFWMD 2010). How can we better measure the benefits from our investments in nature?

\section{Measuring the Value of Water Using Resource Economics}

Florida's water resources can be described as a component of "capital" that we all benefit from-natural capital. All forms of capital-equipment (that is, manufactured capital), people's skills (i.e., human capital), social norms (that is, social capital), and natural capital-help increase our overall wealth. And all types of capital provide us with a flow of services. Natural capital includes all elements of nature, such as minerals, geology, land, water, and living things (Smith et al. 2017). Natural capital is important for providing us with ecosystem services, such as drinking water or recreation. Investments in natural capital translate into an improved flow of ecosystem services from which we all benefit.

Ecosystem services are the goods and services that people derive from nature (see the first article in this series here)."Ecosystem services" is an overarching term that includes various subcategories of services, such as cultural, provisioning, supporting, and regulating ecosystem services. Tourism and tap water are ecosystem services that we can easily relate to; however, many natural processes provide real benefits to us, even though they are not easily observed or experienced. This article focuses on these less-observable ecosystem services that are very important but often hidden from our eyes. These are called "supporting" and "regulating" ecosystem services (MEA 2005).

1. This document is FE1096, one of a series of the Food and Resource Economics Department, UF/IFAS Extension. Original publication date Mary 2021. Visit the EDIS website at https://edis.ifas.ufl.edu for the currently supported version of this publication.

2. Tatiana Borisova, associate professor; Fei He, PhD student; Xiang Bi, assistant professor; Kelly Grogan, associate professor; Food and Resource Economics Department; UF/IFAS Extension, Gainesville, FL 32611.

The Institute of Food and Agricultural Sciences (IFAS) is an Equal Opportunity Institution authorized to provide research, educational information and other services

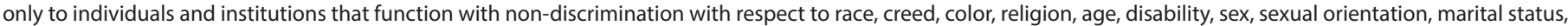

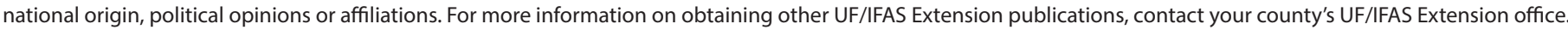
U.S. Department of Agriculture, UF/IFAS Extension Service, University of Florida, IFAS, Florida A \& M University Cooperative Extension Program, and Boards of County Commissioners Cooperating. Nick T. Place, dean for UF/IFAS Extension. 
Supporting services got their name because they support all other ecosystem services, and therefore their impacts on people are indirect. Examples of such services are nutrient cycling, water cycling, and provisioning of habitat (MEA 2005). In turn, regulating services are "benefits obtained from the regulation of ecosystem processes" (MEA 2005), such as flood control, aquifer recharge, timing and magnitude of runoff, or water purification. Often the same ecosystem process contributes to both regulating and supporting ecosystem services (MEA 2005).

\section{Did you know? Ecosystem is...}

"A swamp, a prairie, an ocean, and a forest are examples of ecosystems. ... An ecosystem is made up of all of the living and nonliving things in an area. This includes all the plants, animals, and other living things that make up the communities of life in an area. An ecosystem also includes nonliving materials-for example, water, rocks, soil, and sand." Encyclopedia Britannica

Since regulating and supporting services are often felt indirectly, measuring their value in economic terms is difficult. Still, this article summarizes two Florida-based studies that do provide estimates of economic value of such services. One study discusses environmental restoration in the Greater Everglades, and the other study focuses on the Suwannee River Basin in north Florida and south Georgia. The studies rely on data collected from public surveys, where questions focus on respondents' willingness to pay (WTP) to support an environmental project or program. In such surveys, programs are described in terms of both environmental outcomes and potential costs. People are then asked how much they are willing to pay for implementing such programs. The differences among their responses allow for an estimation of the demand for the services.

\section{Ecosystem Services Related to Restoring the Greater Everglades}

The Greater Everglades includes an interconnected system of wetlands stretching from the southern outskirts of Orlando to the southern tip of Florida's peninsula. Once described as a vast and shallow "river of grass" flowing from Lake Okeechobee, the Everglades were ditched and drained beginning in the 1920s. These draining activities were intended to provide for the necessary flood protection and surface water supply for development in southeastern Florida. Extensive land use and hydrological changes reduced the area of the Everglades wetland system by half of its original extent, and significantly changed the natural flow of water, resulting in considerable environmental damage (Milon and Scorgin 2006). In the early 1990s, the US Congress authorized an initial evaluation of the feasibility of Everglades restoration. In 2000, the Comprehensive Everglades Restoration Plan (CERP) was passed, describing the "blueprint" for this restoration project.

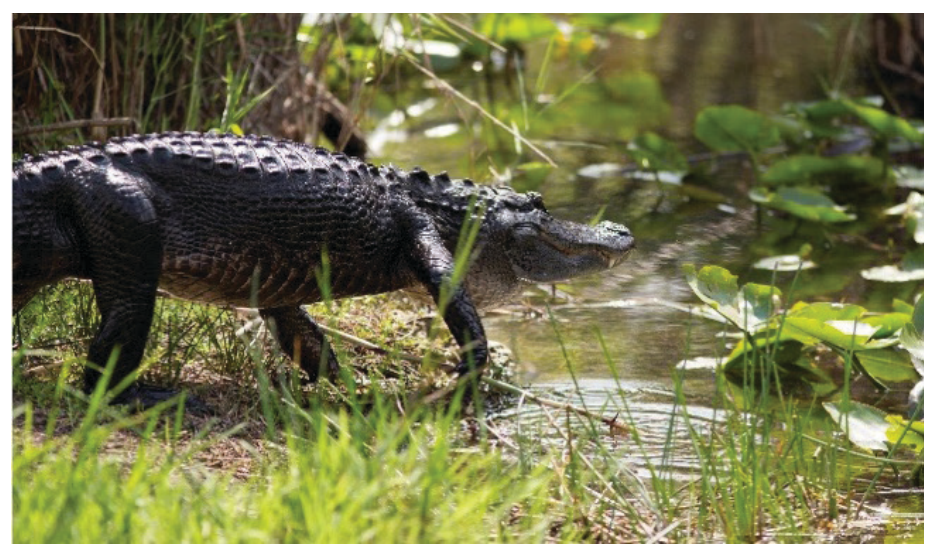

Figure 2. An alligator at Everglades National Park.

Credits: UF/IFAS image

Milon and Scorgin (2006) focus on two sets of ecosystem service metrics that can describe the Everglades restoration endpoints. The first metric relates to the regulation of water flows and levels (i.e., restoring hydrologic functions). Particularly, this applies to water levels for Lake Okeechobee, associated Water Conservation Areas, and the Everglades National Park. The second metric is related to changes in the population of terrestrial and aquatic life in the area. These changes include wetland-dependent species (such as wading birds and alligators); dryland-dependent species (such as deer, hawks, and songbirds), and estuarinedependent species (such as pink shrimp, mullet, and sea trout). For both groups of ecosystem service metrics, the goal of the restoration efforts is to restore the system to match the historic, pre-drainage levels.

Milon and Scorgin (2006) assessed the value that Floridians assign to Everglades restoration and examined how that estimated value changed depending on the ecosystem service metrics used to describe the outcome. To help study participants to evaluate economic tradeoffs, the authors assumed that the restoration would require an increase in the household utility bill, indoor and outdoor water-use restrictions (in south Florida), and conversion of farmland acreage to wetlands (in south Florida). In total, 480 interviews were conducted with households in five Florida cities: Miami, Fort Myers, Orlando, Tampa, and West Palm Beach. Note that the interviews were conducted in 1998, and the value estimates are reported in 1998 US dollars.

The average willingness to pay for restoring the hydrologic functions (water flow) was $\$ 29.33$ per household per year. Interestingly, willingness to pay was higher when Everglades restoration was described in terms of restoring the population of terrestrial and aquatic life, where the average 
willingness to pay was $\$ 59.26$ per household per year. The study also found significant variability in the willingness to pay among groups of respondents, with some respondents opposing restoration efforts and having negative willingness to pay or expressing distrust in the plans.

The study does not provide an estimate of the total value of the Everglades restoration, likely due to the large variability in the willingness to pay among households. However, an earlier analysis in Milon et al. (1999) uses the same survey interview data to estimate the total willingness to pay for the full restoration scenario at \$342.2-\$406.5 million annually. The authors noted that support for the restoration plan (and hence, willingness to pay) declines rapidly if the restoration scenarios impose significantly higher costs in the form of water supply restrictions, losses in farmland acreage, and increases in annual household taxes.

Aside from restoring hydrologic functions and support for aquatic and terrestrial life, the Everglades provides other regulating ecosystem services. A study by Alongi (2012) examined carbon storge in mangrove forests in the Everglades national park, and the regulating ecosystem service related to climate change mitigation. The forests are estimated to store an astounding 106.9 billion pounds of total organic carbon (a median value reported in Jerath et al. [2016]), helping to avoid damages related to climate change. As a part of The Comprehensive Everglades Restoration Plan (CERP), the total cost of preserving natural habitat in the Everglades is calculated to be $\$ 18.3$ billion, and since mangrove forests cover approximately 15 percent of the Everglades area addressed by CERP, the cost of preserving mangroves can be approximated at 0.15 $\star \$ 18.3$ billion $=\$ 2.7$ billion. Further, given the amount of carbon stored in the mangroves, these costs can be used to measure the price that society de facto agreed to pay to keep the carbon sequestered in the Everglades mangroves. This "price" can be approximated as $\$ 0.025$ per lb. of carbon ( $\$ 2.7$ billion divided by 106.9 billion pounds of total organic carbon). This value can be used as a proxy for the potential economic loss due to carbon emission if society fails to prevent the mangroves' degradation due to future external threats.

\section{Nutrient Control and Other Ecosystem Services in the Suwannee River Basin}

Ecosystems support a variety of processes, including nutrient cycling among soil, plants, animals, and atmosphere (Silveira et al. 2018). Human activity can distort the nutrient cycling processes, resulting in an accumulation or deficit of nutrients in the water, soil, or other stages of the natural cycle. Chaikaew et al. (2017) examined the willingness to pay for nutrient control (i.e., supporting the ecosystem service of nutrient cycling) by the residents of the Suwannee River Basin in Florida. This study also included questions about other ecosystem services, specifically, climate control provided by ecosystem services (i.e., a regulating ecosystem service) and agriculture/silviculture production (i.e., a provisioning ecosystem service) in the basin.

The survey responses showed that of nutrient control, climate control, and agriculture/silviculture production, the ecosystem service with the highest value was nutrient control. This result implies that residents in the Suwannee River Basin are concerned about water quality impairment. Although nutrient cycling and nutrient control are processes that are difficult to observe or relate to, they can impact well water quality (i.e., drinking water) or river water quality including river ecosystem health, wildlife habitat, and recreational opportunities.

However, the overall willingness to pay for protecting the three ecosystem services (nutrient cycling, climate control, and agriculture/silviculture production) was relatively low, with the average willingness to pay for all three services being less than $\$ 2$ per household per year. Note that many residents in the area have relatively low incomes. For example, about 40 percent of households earn less than $\$ 50,000$ per year. These low incomes partially explain households' low willingness to pay. Many people outside the Suwannee Basin may be willing to pay for ecosystem service improvement in the basin, and, therefore, expanding the survey scope to the neighboring regions may increase the overall willingness to pay estimate.

\section{Conclusion}

The impacts of supporting and regulating ecosystem services on human well-being are indirect, or they occur over a long time period, and therefore, it can be difficult to accurately measure the dollar-value of such services. Yet, these studies indicate that such ecosystem services can have high values. This is particularly true when an especially unique system like the Everglades is considered. The Everglades combines diverse natural features and ecosystems (NPS 2015) and covers large areas. Carbon sequestration (mitigating climate change), water flow regulation, and wildlife habitat are examples of supporting and regulating ecosystem services provided by the Everglades, as well as other water resources. Economic studies can help better 
understand the economic benefits provided by these and other water-related ecosystems in Florida. The economic estimates can help educate the public about the importance of investing in nature protection and restoration.

Acknowledgement: The authors acknowledge funding for the project "Water resources and human society: educating Floridians about the value of water resources" from UF Thompson Earth Systems Institute (TESI): Earth Systems Grants. TESI aims to support projects by UF students and postdoctoral fellows that communicate Earth systems research to the institute's audiences. See more at: TESI, https://www.floridamuseum.ufl.edu/earth-systems/blog/ announcing-the-2018-ties-grant-recipients/.

\section{References}

Alongi, D. 2012. "Carbon Sequestration in Mangrove Forests." Carbon Management 3 (3): 313-322. DOI: $10.4155 / \mathrm{cmt} .12 .20$

Chaikaew P., A. Hodges, and S. Grunwald. 2017. "Estimating the Value of Ecosystem Services in a Mixed-Use Watershed: A Choice Experiment Approach." Ecosystem Services 23:228-237.

Encyclopædia B. 2020. Ecosystem. https://kids.britannica. com/kids/article/ecosystem/433377

Jerath, M., M. Bhat, V. H. Rivera-Monroy, E. CastañedaMoya, M. Simard, and R. R. Twilley. 2016. "The Role of Economic, Policy, and Ecological Factors in Estimating the Value of Carbon Stocks in Everglades Mangrove Forests, South Florida, USA." Environmental Science \& Policy 66:160-169.

Milon, J. W., A. W. Hodges, A. Rimal, C. F. Kiker, and F. Casey. 1999. "Public Preferences and Economic Values for Restoration of the Everglades/South Florida Ecosystem." Economics Report 99-1, Food and Resource Economics Department, University of Florida, Gainesville, FL. https:// fred.ifas.ufl.edu/pdf/economic-impact-analysis/er99-1.pdf

Milon, J. W., and D. Scrogin. 2006. "Latent preferences and valuation of wetland ecosystem restoration." Ecological Economics 56(2):162-175.

http://www.sciencedirect.com/science/article/pii/ S0921800905000571

Millennium Ecosystem Assessment (MEA). 2005. Millennium Ecosystem Assessment: Ecosystems and Human Well-being. Island Press, Washington, D.C.
National Park Service (NPS). 2015. Ecosystems: Mangrove. https://www.nps.gov/ever/learn/nature/mangroves.htm

Silveira, M. L., J. M. B. Vendramini, H. M. da Silva, and M. Azenha. 2018. "Nutrient Cycling in Grazed Pastures." EDIS 2013 (2). https://doi.org/10.32473/edis-ss578-2013

Smith, A. C., P. A. Harrison, M. Pérez Soba, F. Archaux, M. Blicharska, B. N. Egoh, T. Eros, et al. 2017. "How natural capital delivers ecosystem services: A typology derived from a systematic review." Ecosystem Services 26: 111-126.

Smith, A. C., P. A. Harrison, M. Pérez-Soba, F. Archaux, M. Blicharska, B. N. Egoh, T. Eros, N. F. Domenech, Á. I. György, R. and Haines-Young. 2017. "How natural capital delivers ecosystem services: a typology derived from a systematic review."

South Florida Water Management District (SFWMD). 2010. Kissimmee River Restoration Project. https://www. sfwmd.gov/sites/default/files/documents/krr_krrep_factstour_sheet.pdf

Swihart, T. L. 2011. Florida's Water: A Fragile Resource in a Vulnerable State. RFF Press 2 Park Square, Milton Park, Abingdon, Oxon. 